\title{
5. Vapaa sivistystyö kansalaistoiminnan kivijalaksi
}

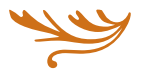

Demokratia ei voi Suomessa hyvin. Äänestysprosentit laskevat ja luottamus poliitikkoihin on pohjalukemissa. Äänestämättä jättäminen alkaa siirtyä monissa perheissä sukupolvelta toiselle. Syitä kehitykselle on haettu erityisesti 1970-luvun perinnöstä. Taistolaisuuden aikana politisoituminen meni koko yhteiskunnassa - erityisesti kouluissa - niin pitkälle, että vastareaktiona politiikkaa alettiin pitää jonain pahana, joka tulee pitää poissa kouluista, yhdistyksistä ja ihmisten keskusteluista. Puoluepolitiikka jätettiin poliitikoille eikä puolueen jäsenyyttä pidetty enää tärkeänä asiana. Tämä on näkynyt demokratiakasvatuksen puutteena kouluissa.

Taistolaisuuden perinnöllä ei voida kuitenkaan selittää suomalaisen demokratian tilaa. Koulutuksen tai tiedon puute eivät ole pääongelma, vaan perimmäinen syy on suomalaisessa poliittisessa järjestelmässä, joka näyttäytyy ihmisille epämääräisenä ja vaihtoehdottomana. Jo Ruotsissa kansalaiset ovat täysin eri tavalla kiinnostuneita vaaleista, koska käytössä on puolueiden keskinäisiä eroja ja periaatteita korostava listavaali ja äänestäjillä on valittavana kaksi vaihtoehtoista blokkia. Ruotsin järjestelmä tuo vaihtoehdot esiin, ja ruotsalaisessa keskustelukulttuurissa uskotaan politiikalla vaikuttamiseen.

Meillä Suomessa listat kerätään täyteen julkimoita ja kaikki puolueet ovat valmiita tekemään suuria kompromisseja päästäkseen hallitukseen. Vain Suomessa vasemmisto ja kristillisdemokraatit löytävät toisensa samasta hallituksesta. Kun ulkomaalaisille 
selittää nykyisen hallituksemme rakennetta, pitävät he sitä täysin absurdina. Ehkä meidänkin pitäisi.

\section{MUUTOS ETENEE ALHAALTA YLÖSPÄIN}

Perussuomalaisten nousu viime vaaleissa oli positiivinen ilmiö. Puolueen nousu ravisteli hyvällä tavalla vanhojen puolueiden vakiintuneita valta-asetelmia. Vaikka perussuomalaisten populismissa ja rasismissa on todella ikäviä piirteitä, puolue onnistui näyttämään, että vaaleissa voi vaikuttaa. Toivottavasti nousu terävöittää kaikkien puolueiden argumentteja, eikä johda vain populististen iskulauseiden heittelyyn ja poliittiseen tähdenlentoon.

Politiikan vaihtoehdottomuuden taustalla on toki suuremmat voimat kuin suomalainen vaali- ja puoluejärjestelmä. Samalla kun talous on globalisoitunut, politiikka on pysynyt pääosin kansallisella tasolla. Tämä johtaa tunteeseen, että talous jyrää pienen Suomen. Suomalaisten poliitikkojen tehtäväksi tulee vain luovia markkinoiden paineessa. Kun yritykset siirtävät tuotantoa ja pääkonttoreitaan ulkomaille, tekevät he omasta näkökulmastaan rationaalisia päätöksiä lainsäädännön puitteissa. Kansalaisille tämä näyttäytyy kuitenkin verokikkailuna ja painostuksena saada valtioita laskemaan palkkoja ja veroja.

Ongelma ei poistu ennen kuin päätöksenteon rakenteet saadaan samalle tasolle globaalin talouden kanssa. Sama ongelma koskee ympäristölainsäädäntöä: ongelmat ovat globaaleja, mutta globaaleista ratkaisukeinoista ei pystytä sopimaan. EU on periaatteessa hyvä alku laajemmalle demokraattiselle päätöksenteolle, mutta sekin kaipaa lisää avoimuutta ja julkista keskustelua.

Mikä sitten olisi vapaan sivistystyön rooli suomalaisen demokratian tilan parantamisessa? Vapaan sivistystyön kursseilla ei pysty muuttamaan suomalaista vaalijärjestelmää saati globaalin päätöksenteon rakenteita. Apatiaa voi silti poistaa.

Tärkeintä demokratian toimimisessa on ihmisen kokemus siitä, että pystyy vaikuttamaan omaan elämäänsä. Usein ihmisillä on liian pessimistinen käsitys vaikutusmahdollisuuksistaan. Vaikuttaminen on paljon muutakin kuin äänestämistä.

Tarvitsemme uskoa tulevaisuuteen kohdatessamme suuria haasteita, kuten ilmastonmuutoksen. Helposti ajattelemme, että emme voi suurille muutoksille mitään. Kuitenkin jokainen voi tehdä oman osansa ja enemmänkin ilmastonmuutoksen torjumisessa yksin ja yhdessä. Yhteiskunnallisen muutoksen tulisi lähteä alhaalta ylöspäin, kun nyky-Suomessa odotetaan liian helposti vain ylhältä tulevia sääntöjä ja ohjeita. Vapaan sivistystyön tulisi tukea ruohonjuuritason demokratiaa.

\section{UUDET LIIKKEET}

Millaista sivistystyötä demokratian hyväksi sitten pitäisi tehdä? Hämeenlinnan kulttuurikeskus Verkatehtaan johtaja Jouko Astor kirjoittaa, ettei Verkatehtaan pidä arvottaa sisältöjä yleisön puolesta. Hän viittaa Pertti Alasuutarin tekstiin teoksessa Toinen tasavalta: "1990-luvun alussa kulttuuripolitiikka menetti kansansivistystehtävän, koska kansa oli jo sivistynyt."

Tässä on pohdittavaa vapaalle sivistystyöllekin. Ehkä vanhalle sivistystyölle työväen akatemioineen ja kansanopistojen pitkine kursseineen ei kerta kaikkiaan ole enää tilausta?

Sivistystyön sijaan on tullut tilausta ammatillisen koulutuksen lisäämiselle, kun työelämä on muuttunut yhä kiivaampaa vauhtia ja uutta ammatillista osaamista on tarvittu. Samalla ihmiset ovat etsineet vapaasta sivistystyöstä uudenlaista sisältöä elämäänsä, kuten kädentaitoja ja kanavia luovuudelle. Vapaan sivistystyön toimijoiden ei pidä itkeä vanhan perään, vaan muuttua maailman mukana. Vapaan sivistystyön roolina ei ole isällisesti kertoa ihmisille, että näin voitte olla aktiivisia, vaan tarjota foorumi aktiivisuudelle.

Suomessa on käynnissä kaksi suurta kehitystrendiä, jotka ovat vapaalle sivistystyölle kohtalonkysymyksiä. Jos näitä kehityskulkuja ei pystytä kanavoimaan voimavaraksi, muuttuu vapaa sivistystyö 1970-luvulla rakennettujen opistojen ulkomuseoksi.

Ensimmäisenä nostan esiin uudenlaisen kansalaisaktiivisuuden, joka on nostanut päätään erityisesti suurissa kaupungeissa. On turha itkeä sitä, että ihmiset eivät kuulu puolueisiin tai toimi aktiivisesti vanhoissa kansalaisjärjestöissä, kun samaan aikaan ihmiset muodostavat sosiaalisessa mediassa lukemattomia erilaisia ryhmiä, keskustelevat, tekevät ja oppivat yhdessä. Vapaa sivistystyö, erityisesti opintokeskukset, on luotu pitkälti tukemaan vanhojen suurien kansalaisjärjestöjen työtä ja koulutuksia. Uudet liikkeet toimivat kuitenkin vanhojen rakenteiden ulkopuolella. 
Erinomainen esimerkki uudenlaisesta yhteisöllisestä oppimisesta oli viime syksynä Helsingin Lapinlahden sairaalan vallannut Koulu - toisilta oppimisen festarit. ${ }^{2}$ Kolmen päivän ajan vanha sairaalarakennus täyttyi oppitunneista, joita kuka tahansa oli saanut ilmoittautua pitämään. Tapahtumalla ei ollut ylhäältä ohjattuja sivistyspäämääriä, mutta silti se vastasi täydellisesti grundtvigilaista opintokerhoideaalia. Miksi vapaan sivistystyön oppilaitokset eivät innosta samalla tavalla? Niiden pitäisi opetella toimimaan uusien liikkeiden kanssa ja luovimaan sosiaalisessa mediassa. Muuten koko sivistystyö muuttuu suurelta osasta kansalaisia epärelevantiksi.

\section{UUDET KOHDERYHMÄT}

On hyvä muistaa, että Koulu-festareissa, kuten useimmissa muissakin vastaavissa kaupunkitapahtumissa, yleisö on koulutettua ja hyväosaista. Koko Suomi ei ole mukana trendikkäissä kansalaisaktiivisuusliikkeissä: Helsingin Jakomäessä 40 \% asukkaista on pelkän peruskoulutuksen varassa. Vieraskielisten osuus on Jakomäessä jo yli $30 \%$. Näissä ihmisissä on toinen ja tärkeämpi - vapaan sivistystyön kohderyhmä.

Maahanmuuttajat ovat sellainen ryhmä, joka tarvitsee juuri sitä, mitä vapaa sivistystyö alun perin tarjosi: mahdollisuuden oppia niillekin, joilla ei ollut siihen mahdollisuutta. Siinä, missä 1920-luvun työläisillä ei ollut varaa oppikouluun, törmäävät 2010-luvun maahanmuuttajat moniin seiniin opiskeluissaan ja työelämässä.
Vapaa sivistystyö nosti aikoinaan monta työväenluokkaista nuorta aina ministereiksi asti. Nyt tarvitaan samanlaista nostetta maahanmuuttajien keskuuteen. Yhteiskunta tarjoaa maahanmuuttajille kotoutumiskoulutusta ja pakollisia kielikursseja, mutta näiden opintojen väliin jää suuri tila maahanmuuttajien omaehtoiselle oppimiselle, opintokerhoille ja järjestötoiminnalle. Tässä on vapaan sivistystyön suuri mahdollisuus. Mikäli maahanmuuttajista ei kasva aktiivisia, omaan ympäristöönsä vaikuttavia kansalaisia, koko Suomi kohtaa suuria vaikeuksia.

Vapaa sivistystyö ei saa olla eliitin norsunluutornistaan kaatamaa sivistystä, vaan aktiivisen kansalaisyhteiskunnan kivijalka, jonka tukemina kansalaiset voivat käydä dialogeja, oppia yhdessä ja sivistyä. Tämä on parasta demokratian edistämistä.

\section{VIITTEET}

1 http://www.luovatkeskukset.fi/keskukset/ haemeenlinna-verkatehdas/ 4.1.2013

2 http://www.kouluschool.org/ 4.1.2013

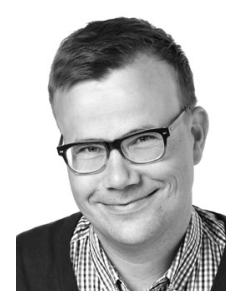

Ville Ylikahri

Vihreän Sivistysliiton pääsihteeri

Opintokeskus Vision opintojohtaja 